ISSN: 2146-3042

DOI: $10.25095 /$ mufad.510619

\title{
Elektronik Vergi Denetimindeki Teknolojik Gelişmeler ve Tam Denetime Geçiş Adımları*
}

\author{
İlker CALAYOĞLU **
}

\begin{abstract}
$\ddot{O Z Z E T}$
Gelișen ve değișen is yapma ortamı ve biçimi nedeniyle ișletmelerde belge ve kayıt ortamı da değișmiștir. Bu sebeple Gelir İdaresi Başkanlığı da bir dizi mevzuat değişikliği ve altyapı geliştirmeleri yapmıs ve yapmaya da devam etmektedir.

Vergi dairelerinin en önemli sorumluluğu mükelleflerin vergi mevzuatına göre hareket edip etmediklerini denetleyebilmesidir. Çünkü vergi kaçırma hali, kamu yararını azaltan bir suçtur. Kamu hakkının korunması için mükellefler bugüne kadar beyan ettikleri bilgiler üzerinden risk odaklı denetim anlayışı ile denetlenmiştir. Bu bağlamda, bu çalışmada söz konusu anlayış ile geliştirilen yazılımlar açıklanmıştır.

Buna ek olarak gelecekte uygulanması düșünülen ve tam denetime imkân verecek olan e-vergi denetim uygulaması Vergi Denetim Analiz Sistemi (VEDAS) ve getireceği ön vergi denetimi anlayışı açıklanmaktadır.

Son gelișmeler çerçevesinde vergi denetiminin tamamının elektronik olarak gerçekleşebilmesi için gerekli olan altyapı, mevzuat ve kontroller hakkında tartışma gerçekleştirilmiştir.

Anahtar Kelimeler: e-Denetim, Risk Odaklı Denetim, Tam Denetim, VEDAS

JEL Sinıflandırması: C88, H26, M42, M48
\end{abstract}

Technological Developments in Electronic Tax Audit and Steps of Changeover to Complete Audit

\section{ABSTRACT}

Due to the evolving and changing business environment and form, the document and recording environment has also changed in the enterprises. For this reason, the Revenue Administration has also made a series of general communique amendments and infrastructure developments. The amendments are kept going on.

The most important responsibility of the tax offices is to control taxpayers whether they act in accordance with tax legislation. Because the state of tax evasion is a crime that reduces the public interest. Until today, taxpayers have been inspected by a risk-focused audit approach on the information they have declared for the protection of the public right. In this context, software that was developed with risk-focused audit approach is explained in this study.

In addition, VEDAS that is an electronic tax audit application that allows for a full tax audit and considered to be implemented in the future and that will bring pre-tax audit conception will be explained.

A discussion will be held on the infrastructure, legislation and controls necessary for the complete realization of tax audits electronically within the framework of the latest developments.

Keywords: e-Audit, Risk-focused Audit, Complete Audit, VEDAS

Jel Classification: C88, H26, M42, M48

Makale Gönderim Tarihi: 16.05.2018

Makale Kabul Tarihi: 12.06.2018

\footnotetext{
* Bu çalışma, 11-13 Ekim 2017 tarihleri arasında Tiran'da gerçekleşen 14th International Conference on Accounting'de sunulan bildiri özetinin genişletilmiş halidir.

** Dr. Öğr. Üyesi, Okan Üniversitesi, İşletme ve Yönetim Bilimleri Fakültesi, Muhasebe ve Denetim Bölümü, ilkercalayoglu@outlook.com
} 


\section{GíRiş}

Bilgisayar ve internetin her geçen gün hız ve kapasitesinin artmasıyla sağlanan yeni ticaret ve iş yapma ortamı, e-ticaret ve e-iş gibi kavramları literatüre kazandırmıştır. Aslında eskiden yaşanan iş süreçlerindeki çoğu işlemin korunduğu ancak ortamının değiştiği ve bu değişim için bir takım yeni terminoloji ve uygulamaların geliştirildiğine şahit olunmaktadır.

Elektronik vergi denetimi öncesinde mevzuatın elektronik belge ve kayıt ortamına uygun şekilde düzenlendiği görülmektedir. Bununla beraber gelecekte yapılması planlanan elektronik vergi denetimi için atılan adımlar da fark edilmektedir. Tabi bu tür hamleler sadece Türkiye'ye has gelişmeler değildir. Küresel olarak gerçekleşen yukarıdaki sebepler gereği tüm ülkelerde kendi altyapı, mevzuat ve üye oldukları birliklerce dönüşüm gerçekleşmektedir. Bu dönüşüme, Maliye Bakanlığı e-dönüşüm süreci ismini vermektedir. Türkiye, söz konusu sürece Fiscalis programları ile entegre olmaktadır.

$\mathrm{Bu}$ çalışmanın amaçları e-dönüşüm sürecinde vergi denetimindeki risk odaklı mevcut elektronik uygulamaları ve sonuçlarını derlemek, yorumlamak; tam elektronik vergi denetimi anlayışııı açıklamak ve böylece meslek mensubu, mükellef ve araştırmacıların gelecekte uygulanması düşünülen süreç ve uygulamalar hakkında bilgi edinmesini sağlayacak literatürü oluşturmaktır.

\section{FISCALIS PROGRAMI VE TÜRKIYYE}

Avrupa Birliği (AB) iç pazarının etkin bir şekilde işlemesi için en önemli araçlardan biri vergilendirmedir. Vergilendirme sisteminin işleyişi, özellikle de vergi kaçırma ve vergiden kaçınma ile mücadele, rekabetin bozulmasının önlenmesi ve idareler ile mükellefler üzerindeki yükün azaltılması açısından önem taşımaktadır. Buradan yola çıkarak, ulusal idareler arasında işbirliği, bilgi değiş̧imi ve en iyi uygulamaların paylaşılmasını sağlamak amacıyla, vergilendirme alanında Fiscalis adı altında bir AB programı oluşturulmuştur. (Karabacak, 2010: 5)

$\mathrm{Bu}$ program, topluluk mevzuatı ile üye ülke mevzuatının uygulanması hakkında ortak bir standarda sahip olmayı, üye ülkeler arasında etkin, verimli ve kapsamlı işbirliği ortamı yaratmayı ve hem idarenin hem de mükelleflerin ihtiyaçlarını dikkate alarak mevcut uygulamaların geliştirilmesini ve yeni ihtiyaçların karşılanmasını amaçlamaktadır. (Gelir İdaresi Başkanlığı, 2012)

$\mathrm{Bu}$ alandaki ilk çalışmalar, dolaylı vergilendirme alanında çalışan kamu personelinin mesleki eğitimi için oluşturulan Mattheus Programı ile gerçekleştirilmiştir. Program, 19931998 yılları arasında devam etmiş ve üye ülkeler arasında bilgi ve personel değişimi sağlamıştır. (Karabacak, 2010: 5) Fiscalis adında ilk program 1998-2002 döneminde iç pazardaki dolaylı vergilerin ıslah edilmesi amacıyla uygulanmış; 2003-2007 döneminde de uygulamaya devam etmiştir. Her iki programın da amaçlarını gerçekleştirmekte başarılı olması, gelecek dönemler için de programa devam edilmesi kararının alınmasına neden olmuştur. (Ubay, 2012: 539) Böylece 11/12/2007'de Avrupa Parlamentosu ve Konseyi; iç pazardaki vergilendirme sisteminin işleyişini geliştirecek Fiscalis 2013 adlı programın 
01.01.2008'den 31.12.2013'e kadar uygulanması kararını almıştır. (Parliament and of the Council, 2007) Programdan sağlanan faydalar nedeniyle Avrupa Parlamento'su 2014-2020 yıllarını kapsayan Fiscalis 2020 programını da başlatmıştır. (Parliament and of the Council, 2013) Program, şu eylemleri kapsar (Eurepean Commission, 2015); (European Parliament and of the Council, 2013):

a) Ortak Eylemler (Katılan ülkelerin yetkililerini bir araya getirmek): Seminerler ve çalıştaylar, proje grupları, idari işbirliği kanununda yer alan diğer faaliyetler, çalışma ziyaretleri, yapılandırılmış işbirliği biçimleri, kamu yönetimi kapasite oluşturma ve destekleme faaliyetleri, iletişim projeleri ve diğer birlikte çalışmalar.

b) Avrupa Bilgi Sistemleri Yapımı: Vergi makamlarını etkin bir şekilde birbirine bağlamak amaciyla Birlik kanununa göre kurulan mevcut Avrupa Bilgi Sistemlerinin Birlik bileşenleri ile yeni Avrupa bilgi sistemlerinin geliştirilmesi, bakımı, işletilmesi ve kalite kontrolünü kapsar.

c) Ortak Eğitim Faaliyetleri: Vergilendirme ile ilgili gerekli mesleki becerileri ve bilgileri desteklemek için ortaklaşa geliştirilmiş eğitim faaliyetleridir.

"Fiscalis Programı faaliyetleri Katma Değer Vergisi, Özel Tüketim Vergisi, gelir ve sermaye üzerinden alınan vergiler, risk yönetimi, e-denetim gibi alanlarda gerçekleştirilmektedir. Bu faaliyetler arasında seminer ve çalıştaylar, çalışma ziyaretleri ve eğitim faaliyetleri ön plandadır." (T.C. Maliye Bakanlığı Avrupa Birliği ve Dış İlişkiler Dairesi Başkanlığı, 2016) Fiscalis 2020 programına AB Üye Devletlerinin ve ülkemizin yanı sıra Arnavutluk, Sırbistan, Karadağ, Makedonya ve Bosna Hersek katılım sağlamaktadır. (Eurepean Commission, 2015)

Türkiye, katılım öncesi stratejilerinden yararlanan bir aday ülke olarak, Fiscalis programına 2003 yılından bu yana katılmaktadır. Mutabakat Zapt1 2003/5797 sayılı Bakanlar Kurulu Kararı ile onaylanmış ve Resmi Gazete'de yayınlanmıştır. (Resmi Gazete, 2003) Fiscalis 2013 programına ise yeni bir karar alınmadan ülkemiz ile Avrupa Komisyonu arasında varılan mutabakat sonucunda aynı koşullar altında katılım sağlanabilmesinde mutabık kalınmıştır. (Karabacak, 2010: 10) Fiscalis 2020 programına katılım için ise yeni karar almak gerekmiştir. (Resmi Gazete, 2014)

"Değerlendirmeler Fiscalis 2013'ün katılımc milli vergi idareleri arasında bilgi değişimi ve yönetsel işbirliğinin geliştirilmesine büyük oranda katkı să̆ladı̆̆ıı göstermektedir. Özellikle Fiscalis 2013, AB içinde özel tüketim vergilerine tabi tüketim mallarının hareketlerinin izlenmesine olanak veren bilgisayarlı sistem sayesinde tüketim alanında önemli ilerlemeler sağlayan Tüketim Hareketleri ve Kontrol Sistemi uygulamaların desteklemistir (daha önce bu kâğlt üzerinde yapılmaktaydı). Bilgi teknolojileri sistemleri; Çok Taraflı Kontroller yoluyla eş zamanlı kontroller sağlamış ve milli idareler arasında gayri resmi ve düzenli işbirliği ile bilgi ve belge değişiminin gelişmesinin desteklenmesinde bir araç olmuşlardır. Fiscalis bundan başka hilecilikle mücadelede erken uyarı sistemi olan Eurofisc 'in uygulamalarını da desteklemiştir." (Ubay, 2012: 550-551)

Fiscalis programı özellikle vergilendirme ve vergi denetimi alanlarında birlik müktesebatı uyumu ve idari kapasitenin geliştirilmesi için gerekli ihtiyaçların karşılanmasını 
sağlayan bir uyum programıdır. "Ülkemizin de katıldı̆̆ bilgisayar ăğ sistemleri denetimlerin etkin işlemesi için bir yol olarak düşünülmektedir." (Bakar, 2012: 43) Mevcut elektronik vergi denetim uygulamalar1 ve gelecekte uygulanmas1 düşünülen süreçlere entegre olabilmek için Fiscalis programlarının oldukça fazla önemi vardır. Vergi Denetim Kurulu (VDK) ve Gelir İdaresi Başkanlığı'nın (GİB) faaliyet raporlarında Fiscalis toplantılarına dair bilgiler sunulmaktadır ve bu toplantılarda e-defter ve e-denetim konuları görüşüldüğü detaylıca raporlanmaktadır.

\section{VERGİ DENETIMINDEKİ RİSK ODAKLI MEVCUT ELEKTRONIK UYGULAMALAR}

İşletmelerin e-ticaret işlemlerine rağbetleri, ödeme yöntemleri ve ticari belgelerin elektronikleşmesi her geçen gün artmakta ve kapsamı genişlemektedir. Muhasebe kayıtları elektronik ortamda oluşturulmakta ve saklanmaktadır. e-Muhasebe "modelinde operasyonların tüm tarafları (çalışan, yönetici, müşteri, kamu kurumları, iş ortaklarl, tedarikçi) sistemin gerçek zamanlı kullanıcılarıdır ve en güncel bilgiyi anlık paylaşırlar." (Hacırüstemoğlu, 2008: 3); (Güney, 2014: 852) "Elektronikleşen muhasebe, denetim teknik ve yöntemlerinin de değişimini să̆lamıştır. Gelinen noktada e-muhasebe, e-denetimi gerekli kılmaktadır." (Calayoğlu, 2017: 30) "Elektronik denetim, elektronik ortam üzerinden yürütülen denetim faaliyetlerinin bütününü oluşturmaktadır." (Alptürk, 2008: 75)

Vergi idaresinin en önemli görevlerinden biri vergi yasalarının doğru şekilde uygulanıp uygulanmadığını kontrol etmektir. Bu kapsamda Gelir İdaresi Başkanlığı, son yıllarda elektronik denetim imkânlarından yararlanarak hem vergi dairelerinin iş ve işlemlerini önemli derecede kolaylaştırmış, hem de mükelleflere dair yeni açılımlar sağlamıştır. (Doğan, 2015:19) Bu kapsamda vergi denetimine dair aşağıdaki risk odaklı edenetim uygulamaları ve kontrol araçları geliştirilmiştir.

\subsection{KDV İadesi Risk Analiz Sistemi (KDVİRA)}

"Ülke genelinde KDV iadesine esas teşkil eden listelerin standart bir şekilde alınmasını sağlamak, vergi dairelerince çoğu kez manuel ortamda yapılan sorgulama ve kontrolleri bir sistem aracllı̆̆ ile yapmak ve günün ekonomik ve teknolojik gelişmelerine paralel bir şekilde iade taleplerine daha hızlı cevap verebilmek amacıyla 2008 yılının Haziran ayında başlatılan çalışmalar sonucunda tasarlanan KDV İadesi Risk Analiz Sistemi (KDVIRA) 2010 Ocak ayından itibaren hayata geçirilmiştir." (Doğan, 2012: 53)

Sistemin işleyişi kısaca şöyledir: Mükelleflerden KDV iadesi talep edenler ebeyannamelerini İnternet Vergi Dairesi'ne yükler. Gönderilen veriler, Gelir İdaresi Veri Ambarı'na ulaşır ve saklanır. Veri ambarındaki veriler Gelir İdaresi Risk Analizi sisteminde veri madenciliği teknikleriyle analiz edilir ve VEDOP sistemi üzerinden vergi dairesine "KDV İadesi Kontrol Raporu” üretilerek iletilir. Bir başka sonuç olan "KDV İadesi Risk Raporu" da Vergi Denetim Kurulu'na gönderilir.

$\mathrm{Bu}$ sistem ile ülkedeki tüm KDV iade talepleri çeşitli açılardan detaylı analizlere tabi tutulmakta ve raporlar iade talebinin yapıldığ 1 günün gecesi tamamlanabilmektedir. KDVIRA, bir gecede on binlerce mükellefin sisteme yükledikleri listelerdeki milyonlarca satır veriyi hem gümrük ve bankalardaki bilgiler ile hem de idarenin kendi bünyesindeki verilerle karşılaştırabilmektedir. (Doğan, 2015: 20) “Bu yönüyle sistem, tamamıyla bir elektronik KDV 
iade denetimi gerçekleştirmesi itibari ile ileride uygulanmass planlanan e-denetim programlarına bir örnek teşkil etmektedir." (Doğan, 2014: 447)

2010 yılından günümüze kadarki süreçte iade talep eden mükelleflerin talepleri, KDVİRA sistemi aracılıyla yukarıda açıklanan raporları üretmiş ve varsa uyumsuzlukları tespit edip mükellef/YMM'lere bildirerek haksız yere KDV iadeleri engellenmiştir. Söz konusu analizler neticesinde ortaya çıan rakamlar GİB'in faaliyet raporlarında açıklanmaktadır. Bunun yanında kayıt dışı ekonomi ile mücadele kapsamında GİB'in belirlediği hedeflere erişmek için yaptığ 1 tahminler, performans programı raporlarında açıklamaktadır. Bu iki rapor türünden ve 2010 yılından itibaren elde edilen performans sonuçları tablo 1'de gösterilmiştir.

Tablo 1. Yıllara Göre İade Talep Eden Mükelleflerin Genel Esas Kontroller Açısından Sonuçları

\begin{tabular}{|l|r|r|r|r|r|}
\hline Yıllar & $\begin{array}{c}\text { İade Talep } \\
\text { Eden } \\
\text { Mükellef } \\
\text { Sayısı }\end{array}$ & $\begin{array}{c}\text { Toplam } \\
\text { Üretilen } \\
\text { Rapor } \\
\text { Sayısı }\end{array}$ & $\begin{array}{c}\text { Risk Analizi Sonrası } \\
\text { Mükelleflerin Genel Esaslara } \\
\text { Tabi Olmak İçin Düzeltme KDV } \\
\text { Beyannamesi İle Tenzil Ettikleri } \\
\text { İade Talebi Tutarı }\end{array}$ & Beklenti ${ }^{1}$ & $\begin{array}{c}\text { Mükellef Başına } \\
\text { Genel Esasların } \\
\text { KDV Tenzil } \\
\text { Ettirme Miktarı }\end{array}$ \\
\hline $\mathbf{2 0 1 0}$ & 32.183 & 284.981 & $200.543 .272 \mathrm{TL}$ & & $6.231 \mathrm{TL}$ \\
\hline $\mathbf{2 0 1 1}$ & 40.465 & 397.678 & $833.988 .683 \mathrm{TL}$ & & $20.610 \mathrm{TL}$ \\
\hline $\mathbf{2 0 1 2}$ & 49.056 & 510.489 & $664.890 .282 \mathrm{TL}$ & $200.000 .000 \mathrm{TL}$ & $13.554 \mathrm{TL}$ \\
\hline $\mathbf{2 0 1 3}$ & 57.754 & 610.506 & $991.000 .813 \mathrm{TL}$ & $200.000 .000 \mathrm{TL}$ & $17.159 \mathrm{TL}$ \\
\hline $\mathbf{2 0 1 4}$ & 66.274 & 718.853 & $1.086 .437 .343 \mathrm{TL}$ & $600.000 .000 \mathrm{TL}$ & $16.393 \mathrm{TL}$ \\
\hline $\mathbf{2 0 1 5}$ & 73.778 & 835.510 & $957.984 .693 \mathrm{TL}$ & $1.000 .000 .000 \mathrm{TL}$ & $12.985 \mathrm{TL}$ \\
\hline $\mathbf{2 0 1 6}$ & 77.516 & 946.526 & $1.257 .051 .987 \mathrm{TL}$ & $1.050 .000 .000 \mathrm{TL}$ & $16.217 \mathrm{TL}$ \\
\hline $\mathbf{2 0 1 7}$ & 83.057 & 1.040 .738 & $1.567 .890 .551 \mathrm{TL}$ & $1.100 .000 .000 \mathrm{TL}$ & $18.887 \mathrm{TL}$ \\
\hline $\mathbf{2 0 1 8}$ & & & & $1.600 .000 .000 \mathrm{TL}$ & \\
\hline
\end{tabular}

Kaynak: Gelir İdaresi Başkanlığı Faaliyet Raporları ve Performans Programları

Tablo 1'e göre iade talep eden mükellef sayısında, her yılın değeri önceki yılla oranlandığında azalan oranda olsa da hep artış gerçekleşmiştir. Artış oranı yüzde 25 'den yüzde 5'e kadar düşmüştür. (Son y1l yüzde 7 olmuştur.) Buna mukabil, üretilen toplam rapor sayısının iade talep eden mükellef başına oranı ise her yıl artarak yükselmektedir. Mükellef başına üretilen rapor sayısı 8,85'den 12,21'e çıkmıştır. Bu durum, KDVİRA sisteminin uygulamaya geçtiğinden beri geliştirildiğini ve daha fazla rapor ürettiğini işaret etmektedir.

Tablo 1'e göre iade talep eden mükelleflere uygulanan genel esas kontrol (GEK) kurallarındaki uyumsuzluklar neticesinde yıllara göre dalgalanan ancak tahminlere göre devamlı artan miktarda KDV iade taleplerinde indirim sağlanmıştır. Tahminlerin her yıl artması ve gerçekleşen rakamların da tahminleri (2015 yılı hariç) hep yakalaması durumu, 2018 yılında gerçekleşecek rakamın da tahminleri yakalama ihtimalini kuvvetlendirmektedir.

\footnotetext{
${ }^{1}$ Gelir İdaresi Başkanlığı'nın yıllara göre Performans Programlarından elde edilen bilgilerdir. Şubat ayında hazırlanır. Geçmiş yıl gerçekleşen rakamları ve içinde bulunulan yıl için de tahmini rakamları bildirir.
} 
$\mathrm{Bu}$ değerleri etkileyen esas unsur, GEK sorgulama parametrelerinin artarak ve geliştirilerek uygulanmasıdır. Her yeni uygulama, iade talep eden mükelleflerin alışma sürecinde oldukları dönemde rakamları arttırmaktadır.

Tablo 2. Y1llara Göre Genel Esas Kontrollerin Sorunlu Alt Mükellef Sonuçları

\begin{tabular}{|l|r|r|r|r|}
\hline \multirow{2}{*}{ Yıllar } & \multicolumn{2}{|c|}{$\begin{array}{c}\text { Sorunlu Alt Mükelleflerin Risk Analizi Sonrası KDV } \\
\text { Matrah Artş Tutarı }\end{array}$} & \multirow{2}{*}{ Toplam } & \multirow{2}{*}{ Beklenti $^{2}$} \\
\cline { 2 - 3 } & $\begin{array}{c}\text { 1.Alt Mükelleflerin Matrah } \\
\text { Artışları }\end{array}$ & $\begin{array}{c}\text { 2.Alt Mükelleflerin Matrah } \\
\text { Artışları }\end{array}$ & \\
\hline $\mathbf{2 0 1 0}$ & $206.691 .852 \mathrm{TL}$ & $339.824 .843 \mathrm{TL}$ & $546.516 .695 \mathrm{TL}$ & \\
\hline $\mathbf{2 0 1 1}$ & $2.076 .881 .611 \mathrm{TL}$ & $3.431 .376 .094 \mathrm{TL}$ & $5.508 .257 .705 \mathrm{TL}$ & \\
\hline $\mathbf{2 0 1 2}$ & $1.852 .938 .965 \mathrm{TL}$ & $1.697 .981 .179 \mathrm{TL}$ & $3.550 .920 .144 \mathrm{TL}$ & $800.000 .000 \mathrm{TL}$ \\
\hline $\mathbf{2 0 1 3}$ & $2.833 .063 .264 \mathrm{TL}$ & $1.968 .690 .830 \mathrm{TL}$ & $4.801 .754 .094 \mathrm{TL}$ & $6.000 .000 .000 \mathrm{TL}$ \\
\hline $\mathbf{2 0 1 4}$ & $4.268 .321 .258 \mathrm{TL}$ & $3.546 .859 .998 \mathrm{TL}$ & $7.815 .181 .256 \mathrm{TL}$ & $3.000 .000 .000 \mathrm{TL}$ \\
\hline $\mathbf{2 0 1 5}$ & $3.637 .912 .071 \mathrm{TL}$ & $2.580 .241 .187 \mathrm{TL}$ & $6.218 .153 .258 \mathrm{TL}$ & $8.000 .000 .000 \mathrm{TL}$ \\
\hline $\mathbf{2 0 1 6}$ & $4.822 .502 .810 \mathrm{TL}$ & $3.969 .727 .011 \mathrm{TL}$ & $8.792 .229 .821 \mathrm{TL}$ & $8.150 .000 .000 \mathrm{TL}$ \\
\hline $\mathbf{2 0 1 7}$ & $6.578 .053 .060 \mathrm{TL}$ & $7.971 .961 .852 \mathrm{TL}$ & $14.550 .014 .912 \mathrm{TL}$ & $7.250 .000 .000 \mathrm{TL}$ \\
\hline $\mathbf{2 0 1 8}$ & & & & $14.000 .000 .000 \mathrm{TL}$ \\
\hline
\end{tabular}

Kaynak: Gelir İdaresi Başkanlığı Faaliyet Raporları ve Performans Programları

Tablo 2'ye göre iade talep eden mükellefin birinci ve ikinci alt mükelleflerinde ortaya çıkan sorunlar nedeniyle KDV matrahlarında artışlar yaşanmıştır. Dolayısı ile mükellefte kalan KDV borcu açığa çıkmıştır. Gerek birinci, gerekse ikinci alt mükellefin matrah artışları yıllara göre dalgalanmaktadır. Alt mükellefler başına en fazla matrah artış miktarları 2017 yılı sonuçlarına aittir. İkisinin toplamı ise dalgalanan ve miktar olarak artan bir görüntü çizmektedir. Bu sonuçlar, son altı yılın tahmini değerleri ile karşılaştırıldığında ekseriyetle tahminlerin aşıldığ 1 (4 kere) ve üçünün aşırı şsekilde olduğu fark edilmektedir. Bu durum, sistemin zamanla geliştirilmesi ve yeni sorgulamalarla zenginleştirilmesinden dolayıdır.

KDV iadesinden sonra ilgili dönem için düzeltme beyannamesi vererek matrah azaltma yoluna giden mükellefler bulunmaktadır. Düzeltme beyannamesi ile art niyetli sonuçları amaçlayanların tespiti için sisteme 11.09.2013 tarihinde yeni bir menü eklenmiştir. Böylece, beyannamenin verildiği günü takip eden gün, vergi daireleri durumdan haberdar olmaktadır. İlgili ekranlara yansıtılan mükelleflere ilişkin bilgiler ve/veya açıklamalar (ihbarname düzenlenmesi vb.) vergi dairelerince takip edilebilmektedir. (Gelir İdaresi Başkanlığ1, 2016: 100-101) Bu uygulamanın başlamasından beri son dört yıllık vergi dairelerince yapılan işlemlerin (ihbarname düzenlenmesi, beyanname tahakkuku vb.) sonuçları tablo 3'te gösterilmiştir.

\footnotetext{
${ }^{2}$ Gelir İdaresi Başkanlığı'nın yıllara göre Performans Programlarından elde edilen bilgilerdir. Şubat ayında hazırlanır. Geçmiş yıl gerçekleşen rakamları ve içinde bulunulan yıl için de tahmini rakamları bildirir.
} 
Tablo 3. İade İşleminden Sonra Düzeltme Beyannamesi Verenlere Kesilen Ceza ve Eklenen Vergi Tutarları

\begin{tabular}{|c|r|r|r|}
\hline \multirow{2}{*}{ Yıllar } & \multicolumn{2}{|c|}{ Vergi Ceza İhbarnamesi ile } & \multirow{2}{*}{$\begin{array}{c}\text { Beyanname ile } \\
\text { Tahakkuk Ettirilen } \\
\text { Vergi Tutarı }\end{array}$} \\
\cline { 2 - 3 } & Tarh Edilen Vergi Tutarı & Kesilen Ceza Tutarı & $5.715 .480 \mathrm{TL}$ \\
\hline $\mathbf{2 0 1 4}$ & $3.970 .987 \mathrm{TL}$ & $4.772 .404 \mathrm{TL}$ & $7.241 .711 \mathrm{TL}$ \\
\hline $\mathbf{2 0 1 5}$ & $24.141 .704 \mathrm{TL}$ & $26.552 .125 \mathrm{TL}$ & $14.777 .997 \mathrm{TL}$ \\
\hline $\mathbf{2 0 1 6}$ & $41.602 .215 \mathrm{TL}$ & $53.044 .970 \mathrm{TL}$ & $18.553 .026 \mathrm{TL}$ \\
\hline $\mathbf{2 0 1 7}$ & $15.516 .440 \mathrm{TL}$ & $17.836 .420 \mathrm{TL}$ & \\
\hline
\end{tabular}

Kaynak: Gelir İdaresi Başkanlığı Faaliyet Raporları

Tablo 3'e göre son zamanların önemli hile noktalarından biri olan düzeltme beyannamesi verip matrah azaltma yoluna giderek vergi kaçıran mükellefler, sistem aracılığ 1 ile tespit edilebilmektedir. Kesilen ceza ve eklenen vergiler ilk üç yıl artmıştır. Son yıl bu yöntemden vazgeçen oldukça mükellef olduğu söylenebilir. GİB, geliştirdiği sistemler ile kayıt dışı ekonomi ile mücadelede önemli kazanımlar elde etmeye başlamıştır.

Son gelişme olarak, KDV iadelerinde risk odaklı denetim anlayışı gereği yüksek riskli iade taleplerini sayısal puan cinsinden tespit eden Riskli İade Takip ve Analiz Programı (RİTAP) geliştirilmiştir. (Gelir İdaresi Başkanlığı, 2017: 84).

\subsection{Sahte Belge Risk Analiz Programı (SARP)}

Risk kriterleri önceden belirlenmiş ve 01.01.2009 tarihinden itibaren faal olan tüm KDV mükelleflerinin sahte belge veya muhteviyatı itibari ile yanıltıcı belge düzenleme risklerini aylık bazda ölçen detaylı analiz imkânı sağlayan bilgisayar programıdır. Mükelleflerin beyanlarından elde edilen bilgilere uygulanan 70 kadar sorgu neticesinde mükellefin risk puanı oluşur. Sahte belge düzenleme ihtimali yüksek olan mükellefler tespit edilerek inceleme elemanlarına inceleme yapılmak üzere gönderilir. (Doğan, 2014: 485-486); (Eray, 2011); (Bakar \& Gerçek, 2016: 233)

2010 y1lından 2013 y1lına kadar 12.704 adet incelemeye sevk edilen mükelleften 4.127 âdetinin denetimi tamamlanmış ve bunlardan \%97,4'ünün sahte belge düzenleyicisi olduğu tespit edilmiştir. (Doğan, 2014: 486) Bu sonuçlar SARP yazılımının çok etkin çalıştığını göstermektedir.

\subsection{Veri Görselleștirme ve Analiz Sistemi (VEGAS)}

Haksız KDV iadesi almak veya ödenecek vergiyi azaltmak isteyen kötü niyetli mükellefleri ve bulundukları organizasyonları da tespit edebilecek bir bilgisayar yazılımıdır. $\mathrm{Bu}$ yazılım ile sahtekâr mükelleflere ait ilişkiler çeşitli düzeylerde görselleştirilerek sunulmaktadır. (Gelir İdaresi Başkanlığı, 2010: 49) Bu düzeyler mükellef, ticari ilişkide bulunulan mükellef, ortaklar-mükellef ilişkisi, mali müşavir-mükellef-vergi dairesi şeklinde sıralanabilir. (Doğan, 2014: 491) Aynı zamanda SARP yazılımı ile de riskleri belirlenen 
mükelleflerin içinde bulunduğu organizasyonun riski anlaşılmakta ve risk odaklı denetim gerçekleştirilebilmektedir.

VEGAS, vergisel ve sektörel analizlerde kullanılmasının yanında Gelir İdaresi Başkanlığı'nın birimlerinin veri erişim ve raporlama ihtiyaçlarını da karşılamaktadır. VEGAS'ın alt uygulamaları ve açıklamaları tablo 4'te özetlenmiştir.

Tablo 4. Veri Görselleştirme ve Analiz Sisteminin Alt Uygulamaları

\begin{tabular}{|c|c|}
\hline Alt Uygulamalar & Açıklamalar \\
\hline $\begin{array}{l}\text { - BA-BS Uygulaması } \\
\text { - Ortaklı Analiz Uygulaması } \\
\text { - Transfer Fiyatlandırma Analiz Uygulaması }\end{array}$ & $\begin{array}{l}\text { Mükelleflerin/Mükellef gruplarının birbirleri ile olan alım satım } \\
\text { ve ortaklık ilişkilerini görsel haritalarla analiz edilmesini } \\
\text { sağlayacak şekilde tasarlanmıştır. }\end{array}$ \\
\hline $\begin{array}{l}\text { - Kullanıcı İzleme Uygulaması } \\
\text { - Sistem İzleme Uygulaması } \\
\text { - Yönetim Uygulaması }\end{array}$ & $\begin{array}{l}\text { Bu uygulamalar kullanıcı tanımlama, tanımlanan kullanıcıların } \\
\text { yetki çerçevesini şekillendirme ve veri güvenliği konusunda } \\
\text { gerekli önlem ve tedbirleri almak adına tasarlanmıştır. }\end{array}$ \\
\hline - Raporlama ve Analiz Uygulaması & 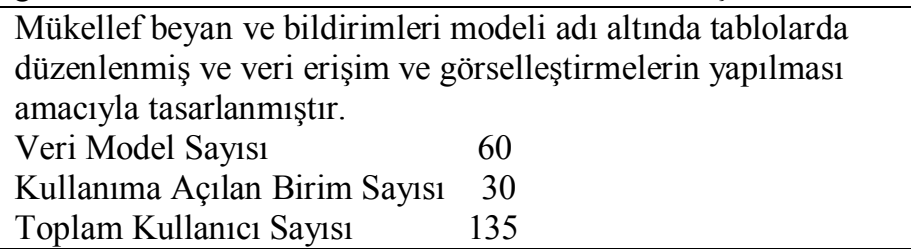 \\
\hline
\end{tabular}

Kaynak: (Gelir İdaresi Başkanlığı, 2015: 101)

Artan kullanıcı sayısı ve model sayısına paralel olarak, veri alt yapısı ve raporlama şekli için yeni gereksinimleri karş1lamak üzere değerlendirme ve geliştirme işlemleri devam etmektedir. (Gelir İdaresi Başkanlığı, 2017: 117)

\subsection{Bandrollü Ürün İzleme Sistemi (BÜİS)}

Toplam vergi gelirlerinin içinde önemli bir paya sahip olan tütün mamulleri ve alkollü içeceklerden alınan ÖTV ve KDV'nin güvence altına alınması gerekmektedir. Bu sebeple üretilen veya ithal edilen tütün mamullerinin ve $5 \mathrm{cl}$ ve daha büyük iç ambalajlı alkollü içki ürünlerinin işaretlenmesi ve Gelir İdaresi Başkanlığı'nda kurulan merkezi veri tabanına aktarılması ve mobil (taşınabilir) cihazlarla saha denetimine imkân sağlanması işlemleri için BÜISS kurulmuştur.

"15 Ocak 2009 tarihinden itibaren, seri üretim hatlarında, ürün bilgilerinin manuel olarak girilmesi uygulamasına son verilerek, ürün bilgisi seçme işlemleri, barkod numarası okutma şeklinde gerçekleştirilmeye başlanmıştır." (Gelir İdaresi Başkanlığ1, 2009: 72)

Sistemin genel işleyişi şu şekildedir: GİB aracılığında veya gözlemciliğinde üretilen bandroller üretici veya ithalatçılar tarafindan tedarik edilir. Üretici veya ithalatçılar ürünlerine söz konusu bandrolleri takar. Bandrollerin aktif edilmesiyle birlikte GİB Merkezi Veri Tabanına internet sayesinde bilgiler akar. Bunun neticesinde mobil denetim cihazları ile denetimler yapılabilmektedir. Bunun yanında bandrollerdeki açık ve gizli bilgiler sayesinde beyan edilecek veya gümrükte ödenecek vergi miktarının önceden hesaplanarak bilinmesine de imkân tanınmaktadır. (Doğan, 2014: 497-512) 
Alkol ve tütün tüketenlerin hem kendileri için hem de vergi denetimine katkıları amaçlanarak 2016 yılı içinde ürünlerin barkodlarını kontrol edebilmeleri amaçlı olarak cep telefonu uygulaması, SMS ve internet sitesinden sorgulama ortamları geliştirilmiştir. (Gelir İdaresi Başkanlığ 1 , 2016: 120)

Mükelleflerin vadesi geçmiş borç, tahakkuk/tahsilat oranı, alınan bandrol, ürüne uygulanan bandrol, bandrol firesi, bandrol stoku, bandrol kullanım oranı, bandrollenen ürün, satış, bandrollü ürün firesi ve Mükellef Bilgi Sistemi'ndeki (MBS) bilgilerinden oluşan kriterlere göre 100 puan üzerinden değerlendirme yapılarak söz konusu firmaların risk ve uyum durumları belirlenmek üzere Bandrollü Ürün İzleme Risk ve Uyum Analiz Projesi (BÜİRAP) oluşturulmuştur. (Gelir İdaresi Başkanlığı, 2016: 119)

BÜİS eğitimleri, başkanlık tarafından yenilenen mevzuatlara uygun olarak verilmeye devam etmektedir. (Gelir İdaresi Başkanlığı, 2017: 104) BÜİS çerçevesinde gerçekleştirilen saha denetim sonuçları tablo 5'te özetlenmiştir.

Tablo 5. Bandrollü Ürün İzleme Sistemi Denetim Sonuçları

\begin{tabular}{|c|r|r|r|r|r|r|r|}
\hline Yıllar & $\begin{array}{c}\text { Denetlenen } \\
\text { Mükellef } \\
\text { Sayısı } \\
\text { Toplamı }\end{array}$ & $\begin{array}{c}\text { Kesilen Özel } \\
\text { Usulsüzlük } \\
\text { Cezası } \\
\text { (ÖUC) } \\
\text { Tutarı }\end{array}$ & $\begin{array}{c}\text { Denetlenen } \\
\text { Ürün } \\
\text { Sayısı } \\
\text { Toplamı }\end{array}$ & $\begin{array}{c}\text { Savcılı̆ga } \\
\text { Bildirilen } \\
\text { Mükellef } \\
\text { Sayısı }\end{array}$ & $\begin{array}{c}\text { Mükellef } \\
\text { Başına } \\
\text { OUUC } \\
\text { Tutarı }\end{array}$ & $\begin{array}{c}\text { Onceki Yıla } \\
\text { Göre ÖUC } \\
\text { Tutarındaki } \\
\text { Değişim }\end{array}$ & $\begin{array}{c}\text { Denetlenenlerin } \\
\text { Savcılı̆̆a } \\
\text { Bildirilme } \\
\text { Oranı }\end{array}$ \\
\hline $\mathbf{2 0 0 9}$ & 197.544 & $4.625 .715 \mathrm{TL}$ & 1.014 .146 & 597 & $23,42 \mathrm{TL}$ & & 0,0030 \\
\hline $\mathbf{2 0 1 0}$ & 279.999 & $4.053 .630 \mathrm{TL}$ & 3.897 .548 & 616 & $14,48 \mathrm{TL}$ & 0,8763 & 0,0022 \\
\hline $\mathbf{2 0 1 1}$ & 304.194 & $3.234 .994 \mathrm{TL}$ & 12.731 .221 & 1.754 & $10,63 \mathrm{TL}$ & 0,7980 & 0,0058 \\
\hline $\mathbf{2 0 1 2}$ & 208.511 & $2.747 .842 \mathrm{TL}$ & 15.787 .572 & 3.232 & $13,18 \mathrm{TL}$ & 0,8494 & 0,0155 \\
\hline $\mathbf{2 0 1 3}$ & 122.942 & $2.046 .892 \mathrm{TL}$ & 12.717 .892 & 10.971 & $16,65 \mathrm{TL}$ & 0,7449 & 0,0892 \\
\hline $\mathbf{2 0 1 4}$ & 107.574 & $1.337 .844 \mathrm{TL}$ & 9.107 .633 & 1.061 & $12,44 \mathrm{TL}$ & 0,6536 & 0,0099 \\
\hline $\mathbf{2 0 1 5}$ & 89.066 & $910.063 \mathrm{TL}$ & 7.987 .874 & 632 & $10,22 \mathrm{TL}$ & 0,6802 & 0,0071 \\
\hline $\mathbf{2 0 1 6}$ & 77.469 & $1.028 .618 \mathrm{TL}$ & 8.247 .661 & 788 & $13,28 \mathrm{TL}$ & 1,1303 & 0,0102 \\
\hline $\mathbf{2 0 1 7}$ & 74.882 & $2.819 .033 \mathrm{TL}$ & 13.792 .020 & 1.674 & $37,65 \mathrm{TL}$ & 2,7406 & 0,0224 \\
\hline
\end{tabular}

Kaynak: Gelir İdaresi Başkanlığı Faaliyet Raporları

Tablo 5'deki özel usulsüzlük cezası kesilmesinin nedenleri, alkol ve tütünlü ürünlerin bandrolsüz, taklit bandrollü veya yanıltıcı bandrollü olmasından dolayıdır. Yıllara göre kesilen özel usulsüzlük cezalarının toplamı dalgalansa da denetlenen mükellef başına düşen özel usulsüzlük cezası tutarı daha stabil durum sergilemiştir. 2017 yılında ise risk odaklı yapılan denetimler neticesinde riski yüksek olan mükelleflere denetim uygulanabildiği için mükellef başına en yüksek özel usulsüzlük cezası tutarı sonucuna erişilmiştir. Ayrıca önceki yıla göre özel usulsüzlük cezası tutarındaki değişimler incelendiğinde son üç yılda artışın olduğu, hele son yılda ise \%174 oranında oldukça fazla miktarda olduğu fark edilmektedir. Denetlenenlerin savcılığa bildirilme oranlarındaki yükselme, yine risk odaklı denetim anlayış ve uygulamalarının etkinliğini destekleyecek şekildedir. 


\subsection{Merkezi Risk Analizi ve Katmanlaştırma Modeli (MERAK)}

Mükelleflerin nesnel risk analizlerine dayalı olarak seçildiği ve mükellefleri bölgeler ve/veya sektörler itibariyle kapsamlara ayıran ve bu sayede mükellefleri belirlenen veriler çerçevesinde büyüklüklerine göre katmanlaştırıp bu katmanlara göre risk analizine tabi tutan yazılımdır. "Incelenecek mükelleflerin seçiminde öncelikli olarak riski yüksek olan mükelleflerin belirlenmesini amaçlayan bu modelde, mükelleflere ait veri ambarındaki veriler istatistiksel ve matematiksel yöntemlerle değerlendirilmektedir. Sektör ve/veya bölgeler itibariyle gruplara ayrlan mükelleflerin bilanço, gelir tablosu, beyanname ve e-VDO verileri ile üçüncü taraf bilgileri baz alınarak büyüklükleri belirlenmekte ve belirlenen bu büyüklüklere göre katmanlara ayrlmaktadır. Böylece, ilgili sektör ve/veya bölgesel kombinasyonda mükellefler en büyük/büyük/orta/küçük katmanlarına göre, her biri kendi sinıfinda analize tabi tutulmakta ve bütünüyle matematiksel ve istatistiki yöntemler ve hesaplamalarla her mükellefe bir risk puanı atanmaktadır." (Gelir İdaresi Başkanlığı, 2010: 10) Her işletmenin kendi sektöründeki ve katmanındaki diğer mükelleflerin hesap değerleriyle karşılaştırılması sonucu ortaya çıkan farklılıklar riski ortaya çıkarmaktadır. Riskli hesabın/ların denetim öncesinde bilinmesi, denetimi kolaylaştırmakta ve etkinleştirmektedir.

"MERAK Modeli, 6009 sayll Kanun ile ihdas edilen Vergi Inceleme ve Denetim Koordinasyon Kurulu'na incelenecek sektörlerin ve mükelleflerin belirlenmesi ve seçimi aşamasında yardımcı olacak araçlardan birisidir." (Gelir İdaresi Başkanlığı, 2010: 50) 2014 yılından itibaren vergi dairesi başkanlıklarına sektör analiz raporları ve sektör bazında uyumsuz değerlere sahip mükellef bilgileri gönderilmektedir. Programın veri alt yapısı ve raporlama şekli üzerinde geliştirme çalışmaları ihtiyaçlar doğrultusunda devam etmektedir. (Gelir İdaresi Başkanlığı, 2014: 107) Uygulamanın adı 2012 yılında Sektör Bilgi Sistemi olarak değiştirilmiştir.

\section{ELEKTRONIK VERGİ DENETIMİ İÇIN STANDART FORMATLAR}

GİB, mükellefleri kendi beyanları üzerinden önceki başlıkta açıklanan araç ve yöntemler ile risk puanları belirlemekte ve buna göre denetim uygulamakta olduğu belirtilmiştir. Fiscalis programı ile vergi dairelerinin uygulamaları birbirine yakınlaştırılabildiği kadar yakınlaştırılmakta; çeşitli sebeplerden ötürü mümkün olmadığ 1 noktalarda ise bilgi alış verişi sağlanmaktadır.

İşletmeler, yerel muhasebe paket programlarından uluslararası markalaşmış kurumsal kaynak planlama yazılımlarına kadar çeşitli seviyelerde muhasebe bilgi sistemleri kullanarak işlemlerini kayıt etmektedir. Tabi her programın birlikte çalıştığı veri tabanı aynı olmamakta veya aynı olsa bile standart bir kayıt formatı bulunmamaktadır. Dolayısı ile veritabanı üzerinden muhasebe kayıtlarının denetimi, muhasebe yazılımına göre geliştirilmiş denetim yazılım programlarını gerektirmektedir. Bu da ayrı bir denetim zorluğudur. Gelecekte vergi dairelerinin mükelleflerin kayıtlarını kaynaktan denetleyebilmesi için muhasebe kayıt formatının standartlaşması gerekmektedir. Bu kapsamda GİB, bir dizi yeni uygulama ile mükelleflerini yönlendirerek kendi denetim anlayış ve sistemlerini geliştirmektedir. 


\subsection{E-Defter}

e-Defter, 13.12.2011 tarihindeki 1 Sıra No'lu e-Defter Genel Tebliği’ne göre, şekil hükümlerinden bağımsız olarak Vergi Usul Kanununa ve/veya Türk Ticaret Kanununa göre tutulması zorunlu olan defterlerde yer alması gereken bilgileri kapsayan elektronik kayıtlar bütünüdür. e-Defterde kullanılan standart, XBRL (eXtensible Business Reporting Language Genişletilebilir İşletme Raporlama Dili) olarak adlandırılan ve Dünya'da gittikçe yaygın bir şekilde kullanılan finansal raporlama alanındaki en esnek dildir. e-Defter, VUK ve TTK çerçevesinde kâğıt ortamda tutulan defterlerle aynı hukuki sonuçları doğurmaktadır. (Resmi Gazete, 2012); (Resmi Gazete, 2015)

İşletmelerde hangi yazılım takip edilerek muhasebe kayıtları tutulmuş olursa olsun (GIBB onayı alan muhasebe yazılımları için) hepsi GİB'in istediği, XBRL formatında raporlama yapmaktadır. Böylece günlük ve büyük defterlerde bir standartlaşma sağlanmış olmaktadır. Türkiye'de elektronik denetim için uygun altyapıyı oluşturmak ve yerleştirmek amacıyla e-dönüşüm uygulamalarının en önemlisi hayata geçmiştir. (Doğan, 2014: 264-265); (Bayar \& Ülkar, 2015: 110); (Özer, 2015: 66-67); (Tercan, 2015: 72)

Şuanda e-defter kullanıcı sayıs1 72.000 civarındadır. (http://www.edefter.gov.tr, 2018) Her mükellef e-deftere geçtiği andan itibaren vergi incelemeleri için e-kayıtlarını ibraz etmekle sorumludur. Dolayısıyla gelecekteki elektronik vergi denetimleri için ilk adım atılmiştır.

\subsection{Kayıt Saklama Gereksinimleri}

Vergi denetim faaliyetlerinin gelişen teknolojilere uygun bir şekilde yürütülebilmesi için mal ve hizmet hareketleri ile ilgili elektronik ortamda oluşturulan kayıtlarda bulunması gereken asgari içeriklerin belirlenmesi, muhafazası ve ibraz edilmesi gerekir. (Resmi Gazete, 2013); (Yıldız \& Baland1, 2015: 42) Tebliğde bildirilen asgari kayıt saklama gereksinimlerinin konuları şunlardır: Alış kayıtları, satış kayıtları, dönem başı ve dönem sonu envanter kayıtları, ihracat kayıtları, ithalat kayıtları, üretim girdi kayıtları, üretim çıtı kayıtları ve diğer kayıtlardır. Her konu hakkında hangi bilgilerin istendiği tebliğin ekinde detaylıca bildirilmiştir. Bu kayıtların istenmesi halinde aşağıdaki formatlardan en az birinde ibraz edilmesi istenmektedir. (Resmi Gazete, 2013)

$$
\begin{aligned}
& -\quad \text {.xls ve .xlsx - Microsoft Excel dosyası, } \\
& \text { - } \quad \text {.txt - Düz metin dosyası, } \\
& \text { - } \quad \text {.csv - Virgül ile ayrılmış değer dosyası, } \\
& \text {.xml - Genişletilebilir işaretleme dili dosyası. }
\end{aligned}
$$

Şimdilik sadece kayıtların istenilen formatlardan en az birinde saklanması istenmektedir. Gelecekte kayıt saklama gereksinimlerinin de standartlaşması beklenmektedir. Öyle ki buna örnek olarak şuanda $\mathrm{AB}$ ülkelerinin uzun süredir üzerinde çalıştıkları vergi denetimine veri sağlama maksatlı oluşturulmuş Standart Denetim Dosyası (Standard Audit File for Tax - SAF-T) bulunmaktadır. Bir benzerinin ülkemizde de hayata geçirilmesi beklenmektedir. (Doğan, 2013: 346 ve 348) 


\subsection{SAF-T}

Vergi için standart denetim dosyası (Standard Audit File for Tax - SAF-T), mükelleflerin vergi denetimi için gerekli bilgilerini standart bir formatta (.xml) sunmay1 amaçlayan ve raporlama gereksinimlerini içeren bir dosyadır. Proje, İktisadi İşbirliği ve Gelişme Teşkilatı (Organization for Economic Co-operation and Development - OECD) çatısı altında yürütülmektedir. SAF-T'nin amacı vergi ve hazine denetim sürecini iyileştirmek ve derinleştirmektir. (http://saf-t.pl/index.html, 2017) Denetim elemanları tarafindan düzen ve format standardizasyonu sayesinde verilerin kolayca okunabilmesi hedeflenmektedir. (Centre for Tax Policy and Andministration, 2005: 3)

Denetçiler artık giderek artan bir doğrulama sorunuyla karşı karşıyadır; bu sayede teknolojideki ilerlemeler ve artan sayıda işletim sistemi, veri biçimi, yedekleme ve dosya saklama seçenekleri görevlerini giderek daha karmaşık hale getirmektedir. SAF-T, hem genel sorunu çözmek amacıyla hem de tamamen elektronik olan modern muhasebe sistemlerine yanıt olarak geliştirilmiştir. (Centre for Tax Policy and Andministration, 2005: 5)

SAF-T, ilk kez 2008'de Portekiz tarafindan kabul edildi. Daha sonra Avusturya, Lüksemburg, Fransa, Polonya ve Litvanya da kabul etti. 2017'nin ikinci yarısında İspanya ve 2018'in başında ise Norveç'in de bu standardı kabul etmesi beklenmektedir. (http://saft.pl/index.html, 2017) SAF-T'yi kabul etme konulu tartı̧̧alar Belçika, Hırvatistan, Finlandiya, Almanya, Litvanya, Malta, İspanya, Slovak Cumhuriyeti, Slovenya ve İngiltere'de gerçekleşti. AB dışında ise Singapur'da işletmeler SAF-T'ye adapte olmaları için teşvik edilmektedir. İsveç ve Hollanda'nın kendi e-denetim dosyası standartları vardır, Almanya'nın ise zorunlu bir elektronik vergi bilançosu bulunmaktadır. (http://www.ey.com, 2017)

SAF-T, .xml formatındadır ve şu verileri kapsar: Günlük defter, büyük defter, müşteriler, satıcılar, vergi matrahları, alış ve satış faturaları, ödeme yöntemlerine göre bilgiler ve stok bilgileri. (Centre for Tax Policy and Andministration, 2005: 12-20)

Özetle muhasebe kayıtlarının tutulduğu yazılımlardaki vergi denetimi için gerekli olan bilgileri elektronik standart bir dosya formatına (.xml) dönüştürülmesi ve vergi dairesine iletilmesini sağlayarak uzaktan denetime imkân verecek altyapının oluşturulması düşünülmektedir.

Türkiye'de kayıt saklama gereksinimleri ilan edilmiştir. Ancak standart bir veri formatı bulunmamaktadır. SAF-T standartlaşmış veri durumunda olduğundan Türkiye'nin, Fiscalis çalışmaları ve OECD yönlendirmesi ile SAF-T'ye geçişi söz konusu olabilir. Tabi bunun için XBRL-GL'deki gelişmeler merakla ve dikkatle takip edilmelidir.

\section{ELEKTRONIK VERGİ DENETIMININ GELECEĞİ}

GİB'in amacı bir yandan kendi iş ve işlem süreçlerini kolaylaştırmak iken, diğer yandan mükelleflere daha kaliteli ve hızlı hizmet sunmaktır. "Vergi teknolojileri ile gelen değişim verginin paydaşların da yakından etkilemektedir. Başsta vergi idareleri olmak üzere, vergi müfettişleri, muhasebeciler, denetçiler ve yeminli mali müşavirler gibi birçok meslek grubu vergisel süreçlerin her aşamasında artı teknoloji ile ilgili kavramlarla karşılaş̧maktadırlar." (Doğan, 2015: 10) Denetlenecek olan defter ve ticari belgelerin 
elektronik olması zorunluluğu, bu kayıt ortamında bir denetimi (e-denetim) zorunlu k1lmaktadır.

Vergi denetimi için e-defterlerin incelenmesi, önceden belirlenmiş çeşitli konularda sorgulama yapabilen, e-defterleri açabilen ve inceleme elemanları tarafindan kullanılabilen bir başka yazılımı gerekli kılmaktadır. (Özer, 2015: 69); (Doğan, 2015: 32)

2015 yllinda OECD ve IOTA (Intra-European Organization of Tax Administrations Avrupa Ülkeleri Vergi İdareleri Organizasyonu) kurumları, genel kabul görmüş e-denetim prensipleri ve yöntemleri belirlemiş, bunlarla ilgili yazılı dokümanlar derlemiştir. $\mathrm{Bu}$ çalışmalara VDK da katılmıştır. Bunun akabinde "filtreleme fonksiyonlarına ve aktarım aracına sahip prototip sunulmuş olup, bu prototip üzerinden geliştirme çalışmalarına devam edilmektedir." (Vergi Denetim Kurulu, 2015: 37)

VDK, 2016 faaliyet raporunda e-kayıtlara odaklı yeni bir e-denetim yazılımından bahsetmiştir.

\subsection{Vergi Denetim Analiz Sistemi (VEDAS)}

Vergi incelemelerinin daha etkin ve kısa sürede tamamlanabilmesi amaciyla geliştirilen, mükellefler tarafindan üretilen e- defter, e-fatura, kayıt saklama verileri gibi elektronik verilerin kullanıldığı yeni bir e-denetim analiz sistemidir. Yazılımın test çalışmaları için görevlendirmeler yapılmış ve geri bildirimlere göre iyileştirici bakımlar uygulanmıştır. Ayrıca, e-fatura kapsamında olmayan mükelleflerin denetiminde de kullanılabilmesi için ibraz edecekleri belgelerin standartlaştırılması düşünülerek ikincil mevzuat çalışmaları yapılmıştır. $\mathrm{Bu}$ durum dönüştürme maliyetinin hesaplanması için önde gelen muhasebe programcıları ile görüşülmüştür. (Vergi Denetim Kurulu, 2016: 38)

Yazılımın tüm vergi müfettişleri tarafından rahatlıkla kullanılabilmesi için standart analizler sisteme kazandırılmış ve demo versiyonu ile test çalışmalarına başlanmıştır. $\mathrm{Bu}$ kapsamda sisteme yüklenen e-defter ve e-faturaların doğruluğunun testi yapılabilecek, efatura görüntülenebilecek, sıralama, filtreleme ve format değiştirerek (.txt, cvs, .xlsx) dişa aktarma işlemleri gerçekleştirilebilecektir. (Vergi Denetim Kurulu 2017: 35)

VEDAS'ın kullanımı konusunda bilgi birikiminin oluşması ve Vergi Müfettişlerine destek kaynak olabilmesi için e-denetim forumu oluşturulmuş ve portal aracıllğ 1 ile hizmete sunulmuştur. (Vergi Denetim Kurulu, 2017: 36)

VEDAS ile yapılan denetim sonuçları Vergi Denetim Kurulu Başkanlığı Bilgi İşlem Sistemi'ne (VDK-BİS) entegre edilebilmiştir. Geliştirme çalışmaları devam etmektedir. (Vergi Denetim Kurulu, 2017: 61)

Şimdilik yukarıdaki kaynak ve bilgiler dışında başka bir bilgi bulunmamaktadır. Yakın gelecekte vergi denetimlerinde bu yazılımın kullanılacağı anlaşılmaktadır. Hem yazılımın sorgulama konularını anlamak hem de mükelleflerin bu konuya uyumunu açıklayabilmek için ön vergi denetiminden bahsedilmesi gerekir.

\section{2. Ön Vergi Denetimi}

Mükelleflerin vergi dairesinden önce kendilerini vergi incelemesine tabi tutmalarıdır. Buna gerçekten ihtiyaç olup olmadığı bir an sorgulanırsa; mükellefin e-defter kayıtlarının 
doğruluğuna olan güveni ve ceza alma riskini ne kadar üstlenebildiği ile alakalı bir durum olduğu şeklinde cevaplanabilir. Çünkü e-defter ve e-fatura GïB'e gönderildiğinde sadece GIBB standardına uygun olup olmadığı açısından değerlendirilmektedir. Genel kabul görmüş muhasebe ilkeleri, tek düzen hesap planı, vergi hukuku gibi önceden belirlenmiş olan kurallara göre doğruluğu test edilmemektedir. E-defter beratı ile de defterlerin değiştirilemezliği sağlanmaktadır. Bu işlemden sonra fark edilecek hatalar, düzeltme kayıtları ile dengelenebilir ancak yapılan hatayı yok etmez. Bu sebeple mükellefler açısından en uygunu defterlerini beratlamadan önce kendilerini ön vergi denetimine tabi tutmalarıdır.

Mükellefler elektronik vergi denetimine nasıl hazırlanabilirler? sorusu düşünülmüş ve özel girişimler sonucu bazı yazılımlar üretilmiştir. Bu kapsamda aralarında Türkiye'nin de olduğu 18 ülkedeki hükümetler ve düzenleyici kuruluşlara uygunluk ve analiz çözümleri sunan IRIS Business şirketinin e-denetim yazılımı bulunmaktadır. IRIS, hükümetler ve düzenleyicilerle birlikte çalışarak yasal raporlama stratejileri konusunda onlara tavsiyelerde bulunmaktadır. (http://www.irisbusiness.com, 2017) Diğer yerli yazılımlar ise İdea Teknoloji Çözümleri AŞ'nin yazılımlarından biri olan Vision Plus VerDe ve Fit Solutions firmasının eDenetleme yazllımlarıdır. (http://verde.ideateknoloji.com.tr, 2017) (https://fitsolutions.com.tr, 2017)

$\mathrm{Bu}$ yazılımlar ile e-defter üzerinden mali tabloların üretilmesi ve işletmeye dair çeşitli oran analizleri ile durum bilgisi sunulmaktadır. Kanun ve tebliğ kaynaklı kurallara göre teknik hata ve eksikler belirlenebilmektedir. Vergi denetimi için vergi mevzuat1, muhasebe kuralları ve TTK'da yer alan sermaye ve kâr dağıtımı ile ilgili zorunluluklar açısından denetim sağlanabilmektedir.

Ön denetimde sorgulanan noktaların mutlaka VEDAS yazılımı tarafindan da sorgulanacağı beklenmektedir. Hatta yeni muhasebe ortamı yeni dijital hileleri de beraberinde getirme olasılığı taşıdığından VEDAS yazılımının, ön vergi denetimi yazılımlarından daha fazla kontrol yapması gerekmektedir. Örneğin; e-defterde sunulan e-mühür ve e-imzanın geçerli olup olmadığı, e-defterin GỉB tarafindan beratlanıp beratlanmadığı, sahte e-fatura sunulup sunulmadığı gibi.

\section{ELEKTRONIK VERGI DENETIMI IÇCiN SON GELIŞMELERIN YETERLİLİĞİ}

Mali raporların kaynağı büyük defter ve yevmiye kayıtlarıdır. Ancak yevmiye kaydının kaynağı ise ticari belgelerdir. Dolayısı ile her ne kadar son gelişmelerde e-defter üzerinden e-denetim yapabilecek yazılımlar geliştirilmiş olsa da tek başına e-defter kayıtları vergi denetimi için yeterli değildir. Ticari belgelerden hangisine bağlı olarak e-defter kaydı oluşturulmuş ise o belgenin yasallığının kontrol edilmesinden sonra belgeye göre doğru şekilde muhasebe kaydı yapılıp yapılmadığının kontrol edilebilmesi gerekir ki kamu hakkının korunması, gerçeğe uygunluk ve şeffaflık sağlanabilsin. Mevcuttaki e-denetim yazılımları en yaygın şekilde kullanılan sadece e-fatura ile eşleştirme yapabilir ve sorgulama yürütebilir; çünkü ticari belgelerden diğerlerinin standartlaşma çabaları sürmekte veya yaygın olarak kullanımları mecburi değildir.

Birleşmiş Milletler Ticareti Kolaylaştırma Merkezi gibi ticari belgeleri standart hale getirmeye çalşan, kamu ve özel sektör kurumları ile uluslararası organizasyonlar 
bulunmaktadır. Bu topluluk tarafından 63 adet ticari belgenin UBL (Universal Business Language-Evrensel Ticaret Dili) kapsamında standart hale getirilmesi çalışmaları tamamlanmıştır. (Doğan, 2013: 113); (Doğan, 2016: 13)

Bu gelişmelere endeksli olarak 487 Sıra No.lu Vergi Usul Kanunu Genel Tebliği sevk irsaliyesi, müstahsil makbuzu ve serbest meslek makbuzu gibi belgelerin elektronikleşerek düzenlenmesi, iletilmesi, muhafaza ve ibraz edilebilmesi istenmektedir. 487 sira numarali tebliğde değişiklik yapılmasına dair tebliğde ise e-faturaya dâhil olmuş olanların 2019 yılı itibari ile zorunlu olarak e-irsaliye kullanmaları gerekecektir. Müstahsil makbuzu ve serbest meslek makbuzunun elektronik olarak kullanımına dair henüz bir zorunluluk yoktur.

Söz konusu standartlaşma çalışmaları neticesinde gelecekte diğer ticari belgelerin (Gider pusulası, kıymetli maden alım-satım belgesi, menkul kıymet alımı, banka hareketleri, senet, poliçe, tahsilat ve tediye fişleri ve ücret bordroları) de sadece elektronik olarak kullanılması muhtemeldir. e-Çek uygulamasında ciddi ilerlemeler sağlanmaktadır. (https://www.btom.org.tr, 2016)

E-Fatura, e-irsaliye ve e-defterde olduğu gibi elektronikleşen ve standartlaşan diğer belgelerin uygulama sürecinin merkezinde düzenleyici kurumun (GİB) olması gerekli ki edenetim yazılımı, düzenleyicinin kurallarını da test edebilsin.

\section{SONUÇ}

$\mathrm{AB}$ uyum süreci, şirketlerin uluslararası olmaları ve ülkelerin farklı vergi mevzuatlarına göre işlem yapması, raporların farklı formatlarda üretilmesi, kamu yararını koruma ve gerçeğe uygunluk ilkeleri gibi birçok nedenden ötürü OECD ülkelerinin vergi dairelerinin uygulamalarının yakınlaştırılması çalışmaları sürmektedir. Ortak payda, günümüz işletmelerinin hem iş yapış şekillerinin hem de muhasebe kayıt ortamlarının değişmiş olduğudur. Bilişim teknolojilerindeki gelişmeler neticesinde iş süreçleri, ticari belgeler ve muhasebe kayıtları elektronik olarak oluşturulmakta, kayıt edilmekte ve gerektiğinde ibraz edilebilmektedir.

Vergi dairelerinin en önemli sorumluluğu mükelleflerin vergi mevzuatına göre hareket edip etmediklerini denetleyebilmeleridir. Çünkü vergi kaçırma hali, kamu faydasını azaltan suçu teşkil eder. Kamu hakkının korunması için mükelleflerin az bir bölümünün değil, mümkünse tamamının denetlenmesi gerekir. Tam da bu noktada elektronik denetim uygulamaları devreye girmektedir.

2011 y1lında kurulan Vergi Denetim Kurulu, mükelleflerin daha etkin ve kapsayıc1 şekilde denetiminin sağlanabilmesi için mükelleflerinin beyanlarına dayalı olarak olası hata, hile vb. aykırılıkların riskini ölçecek çeşitli yazılımlar geliştirmiştir. Riske odaklanan edenetim anlayışıyla birlikte e-defter ve e-fatura uygulamalarının hayata geçmesi, VDK'ya yeni bir soluk kazandırmıştır. Buna göre e-defter ve e-faturaları okuyabilen elektronik denetim yazılımı (VEDAS) ile işletmenin tüm mali durumu, vergi mevzuatına uyum seviyesi, teknik açıdan e-belge ve kayıtlarının geçerliliğinin olup olmaması yönünde denetleme yapabilecektir. Öyle ki mükellefin iş yerine gidilmesine bile gerek kalmayacaktır. Vergi inceleme memurları, mükellefin e-defter ve e-faturalarının bulunduğu alana uzaktan erişimiyle denetim sağlayacak ve sonuçları mükellefe tebliğ edilebilecektir. Böylece tam 
denetim hedefi kolaylaşmış olmakta, hatta önceden hazırlanmış beyannameler dönemine geçilmesi sağlanabilecektir. İdarenin bu teknolojik üstünlüğü, mükelleflerin hata ve hilelere yönlenmelerini azaltacaktır. Ancak e-defterlerin değişmezliği sağlandığından mükellefin edeftere geçtiği andan itibaren yaptığı usulsüzlükler ceza kaynağı olarak kalacaktır.

Mükelleflerin VEDAS gibi bir yazılım ile denetlenmeden önce söz konusu denetime veri teşkil edecek olan e-defter ve faturalarını kendileri denetlemelidir. VEDAS yazılımında sorgulanan kriterlere paralellik gösteren özel sektör e-denetim yazılımları bu amaç için geliştirilmiş ve sayılarının artması beklenmektedir. GİB, e-defter uygunluk onayı almış olan muhasebe yazılımlarını listelediği gibi gelecekte kendi parametreleri ile uyumlu çalışan ön edenetim yazılımlarını da listeleyebilir. Böylece mükelleflerin vergi teknolojileri ve vergi mevzuatına uyumu beraber sağlanabilir.

Vergi denetimlerinin daha geniş kitlelere yayılmasıyla idarenin vergi toplama gücünün artması beklenmektedir. Vergi toplama gücünün artması, kayıt dışı ekonomi ile mücadele ve vergide adalete doğru çok olumlu kazanımlar sağlayacaktır.

\section{KAYNAKLAR}

Alptürk, E. (2008), Elektronik Denetim Rehberi, 1. Baskı, Kurtiş Matbaacılık, İstanbul.

Bakar, F. - Gerçek, A. (2016), "Vergi Denetiminde Risk Analizinin Yeri: Bazı Ülke Uygulamaları ve Türkiye İçin Bir Değerlendirme”, 31. Maliye Sетроzyumu, ss. 217241 ,

Mersin. http://maliyesempozyumu2016.mersin.edu.tr/31_turkiye_maliye_sempozyumu.pdf

Bakar, F. (2012), "Vergi İdareleri Arası İşbirliği: Fiscalis Fiscus Programları", Ekonomi Bilimleri Dergisi, $\quad$ Cilt: $4, \quad$ Sayl: $2, \quad$ ss.35-44. http://www.sobiad.org/ejournals/dergi_EBD/arsiv/2012_2/feride_bakar.pdf

Bayar, S. - Ülkar, M. G. (2015), "E-Defter ve E-Fatura Teknik Analizi: Örnek Bir Uygulama", Vergi Sorunlar1 Dergisi, Sayi: 322, ss. 102-110. http://vergisorunlari.com.tr/makale/e-defter-ve-e-fatura-teknik-analizi-ornek-biruygulama/8007

Calayoğlu, İ. (2017), “Türkiye'deki Ön Lisans ve Lisans Düzeyinde Muhasebe ve Denetim Alanlarının Öğretiminde Yazılımın Yeri ve Elektronikleşen İş Ortamı”, 1. Uluslararası Uygulamalı Sosyal Bilimler Kongresi, Ușak, ss. 30-34,

Centre for Tax Policy and Andministration, (2005), Guidance for the Standard Audit File Tax, http://www.oecd.org/tax/administration/34910277.zip [Erişim Tarihi: 11.11.2017]

Doğan, U. (2012), "KDV İadesi Risk Analiz Sistemi (KDVIRA)”, Vergi Sorunları Dergisi, Sayl: 288, ss.53-61. http://vergisorunlari.com.tr/makale/kdv-iadesi-risk-analiz-sistemi--kdvira-/6455

Doğan, U. (2013), 550 Soruda e-Fatura ve e-Defter, 3. Baskı, Seçkin Yayıncılık, Ankara. 
Doğan, U. (2014), Elektronik Vergisel Uygulamalar, 1. Baskı, TÜRMOB Yayınları, Ankara.

Doğan, U. (2015), "Vergi Teknolojileri”, Vergi Sorunları Dergisi, Sayı: 322, ss. 9-40. http://www.vergisorunlari.com.tr/makale/vergi-teknolojileri/7994

Doğan, U. (2016), "Robotik Denetim", Vergi Sorunları Dergisi, Sayı: 329, s.7-22. http://www.vergisorunlari.com.tr/makale/robotik-denetim/8083

Eray, B. (2011), “Elektronik Ortamda Defter Tutma Dönemi Geliyor”, https://www.burhaneray.com/Makale/elektronik-ortamda-defter-tutma-donemigeliyor_191.aspx [Erişim Tarihi: 13.10.2017]

Eurepean Commission, (2015), Participating in Fiscalis 2020, https://ec.europa.eu/taxation_customs/fiscalis-programme/participating-fiscalis2020_en [Erişim Tarihi: 18.10.2017]

European Parliament and of the Council, (2013), On 11 December 2013 Establishing an Action Programme to Improve the Operation of Taxation Systems in the European Union for the Period 2014-2020 (Fiscalis 2020) and Repealing Decision No 1482/2007/EC. http://eur-lex.europa.eu/legalcontent/EN/TXT/?uri=uriserv:OJ.L_.2013.347.01.0025.01.ENG\&toc=OJ:L:2013:347: TOC

European Parliment and of the Council. (2007). On 11 December 2007 Establishing a Community Programme to Improve the Operation of Taxation Systems in the Internal Market (Fiscalis 2013) and Repealing Decision no 2235/2002/EC. http://eur-lex.europa.eu/legalcontent/EN/TXT/?uri=celex\%3A32007D1482

Gelir İdaresi Başkanlığı, (2009). Faaliyet Raporu, Maliye Bakanlığ1, Ankara. http://www.gib.gov.tr/sites/default/files/fileadmin/faaliyetraporlari/2009/2009_faaliyet _raporu.pdf

Gelir İdaresi Başkanlığı, (2010). Faaliyet Raporu, Maliye Bakanlığ1, Ankara. http://www.gib.gov.tr/sites/default/files/fileadmin/faaliyetraporlari/2010/Faaliyet_rapo ru_2010.pdf

Gelir İdaresi Başkanlığı, (2012), Fiscalis 2013 Programı, http://www.gib.gov.tr/node/102506 [Erişim Tarihi: 16.10.2017]

Gelir İdaresi Başkanlığı, (2014). Faaliyet Raporu, Maliye Bakanlığı, Ankara. http://www.gib.gov.tr/sites/default/files/fileadmin/faaliyetraporlari/2014/2014_Faaliye t_Raporu.pdf

Gelir İdaresi Başkanlığı, (2015). Faaliyet Raporu, Maliye Bakanlığı, Ankara. http://www.gib.gov.tr/sites/default/files/fileadmin/faaliyetraporlari/2015/2015_faaliyet _raporu.pdf 
Gelir İdaresi Başkanlığı, (2016). Faaliyet Raporu, Maliye Bakanlığ1, Ankara. http://www.gib.gov.tr/sites/default/files/fileadmin/faaliyetraporlari/2016/2016_faaliyet _raporu.pdf

Gelir İdaresi Başkanlığı, (2017). Faaliyet Raporu, Maliye Bakanlığ1, Ankara. http://www.gib.gov.tr/sites/default/files/fileadmin/faaliyetraporlari/2017/2017_faaliyet _raporu.pdf

Güney, A. (2014), "Role of Technology in Acconting and e-Accounting", Social and $\begin{array}{llll}\text { Behavioral Sciences, } & \text { Say1: } & \text { 152, 852-855. }\end{array}$ doi:https://doi.org/10.1016/j.sbspro.2014.09.333

Hacırüstemoğlu, R. (2008), "Bilgi Çağında Muhasebe Eğitimi”, Muhasebe Bilim Dünyası Dergisi, Cilt: 10, Sayı: 3, s.1-6.

Karabacak, N. S. (2010), Avrupa Birliği'nin Vergilendirme Alanındaki Fiscalis Programı ve Türkiye'nin Katılımı, Maliye Bakanlığı Avrupa Birliği ve Dış İlişkiler Dairesi Başkanlı̆̆ 1 , Ankara. http://www.abmaliye.gov.tr/ABDID\%20Raporlar/Ara\%C5\%9Ft\%C4\%B1rma\%20ve $\% 20 \% \mathrm{C} 4 \% \mathrm{~B} 0$ nceleme $\% 20$ Serisi/ABnin\%20Vergilendirme $\% 20 \mathrm{Alan} \% \mathrm{C} 4 \% \mathrm{~B} 1$ ndaki\% 20Fiscalis\%20Program\%C4\%B1.pdf

Özer, E. (2015), “Vergi İncelemesinde Yeni Dönem: E-Defter”, Vergi Sorunları Dergisi, Say1: 322, s.65-70. http://vergisorunlari.com.tr/makale/vergi-incelemesinde-yeni-donem-e-defter/7999

Resmi Gazete, (2003), 2003/5797 Türkiye'nin Fiscalis 2003-2007 Topluluk Programına Katılımı Hakkında Türkiye Cumhuriyeti ve Avrupa Topluluğu Arasında Mutabakat Zaptı'nın Onaylanması Hakkında Karar, Ankara. http://www.resmigazete.gov.tr/eskiler/2003/07/20030704.htm\#4

Resmi Gazete, (2012), Vergi Usul Kanunu Genel Tebliği - Sıra No: 421, Maliye Bakanlı̆̆g, Ankara. http://www.resmigazete.gov.tr/eskiler/2012/12/20121214-15.htm

Resmi Gazete, (2013), Vergi Usul Kanunu Genel Tebliği - Sıra No: 431 Maliye Bakanlığg, Ankara. http://www.resmigazete.gov.tr/eskiler/2013/12/20131229-3.htm

Resmi Gazete, (2014), 2014/6809 Türkiye Cumhuriyeti ve Avrupa Birliği Arasında Türkiye Cumhuriyeti'nin Birliğin Fiscalis 2020 Programına Katılımına İlişkin Anlaşmanın Onaylanmasına İlişkin Karar, Ankara. http://www.resmigazete.gov.tr/eskiler/2014/10/20141002-1.htm

Resmi Gazete, (2015), Vergi Usul Kanunu Genel Tebliği - Sıra No: 454, Maliye Bakanlığg, Ankara. http://www.resmigazete.gov.tr/eskiler/2015/06/20150620-18.htm

T.C. Maliye Bakanlığı Avrupa Birliği ve Dış İlişkiler Dairesi Başkanlığı, (2016), Fiscalis 2020 Programı ve Türkiye'nin Kat1lım1, http://www.abmaliye.gov.tr/Sayfalar/35FISCALIS.aspx [Erişim Tarihi: 25.08.2017] 
Tercan, Y. (2015), “Elektronik Defter Standardı: XBRL”, Vergi Sorunları, Sayı: 322, s.71-85. http://www.vergisorunlari.com.tr/makale/elektronik-defter-standardi-xbrl/8000

Ubay, B. (2012), "Vergilendirme Alanında Avrupa Birliğinin İşbirliği Aracı: Fiscalis 2013 Programı", Maliye Dergisi, $\quad$ Sayı: 162, s.538-560. https://dergiler.sgb.gov.tr/calismalar/maliye_dergisi/yayinlar/md/162/27.pdf

Vergi Denetim Kurulu, (2015), Faaliyet Raporu, Maliye Bakanlığı, Ankara. https://www.vdk.gov.tr/File/?path=ROOT\%2f1\%2fDocuments\%2fDosya\%2fFaaliyet Raporu_2015.pdf

Vergi Denetim Kurulu, (2016), Faaliyet Raporu, Maliye Bakanlığı, Ankara. https://www.vdk.gov.tr/File/?path=ROOT\%2f1\%2fDocuments\%2fDosya\%2fVDK\%2 02016\%20Faaliyet\%20Raporu_22.05.17.pdf

Vergi Denetim Kurulu, (2017), Faaliyet Raporu, Maliye Bakanlı̆̆g, Ankara. https://www.vdk.gov.tr/File/?path=ROOT\%2f1\%2fDocuments\%2fDosya\%2f2017VD KFaaliyetRaporu.pdf

Yıldız, C. - Balandı, C. (2015), "Elektronik Denetime Doğru”, Vergi Sorunları Dergisi, Sayı: 322 , s.41-44. http://vergisorunlari.com.tr/makale/elektronik-denetime-dogru\%E2\%80\%A6/7995

http://saf-t.pl/index.html, [Erişim Tarihi: 23.09.2017]

http://verde.ideateknoloji.com.tr/, [14.09.2017]

http://www.edefter.gov.tr/edefterkayitlikullanicilar.html, [12.05.2018]

http://www.ey.com/gl/en/services/tax/vat--gst-and-other-sales-taxes/ey-ch1-4-deliver-yourdata-on-time-and-in-the-right-format, [23.09.2017]

http://www.irisbusiness.com/solution/government-regulator [14.09.2017]

https://fitsolutions.com.tr/tr/e-denetleme, [14.09.2017]

https://www.btom.org.tr/Upload/doc01893920160427150510.pdf [18.12.2017] 
(81): 143- 162 